Published in final edited form as:

Clin Immunol. 2017 September ; 182: 4-13. doi:10.1016/j.clim.2017.04.003.

\title{
Innate immunity in Sjögren's syndrome
}

\author{
Jeremy Kiripolsky ${ }^{1}$, Liam G. McCabe ${ }^{1,{ }^{*}}$, and Jill M. Kramer ${ }^{1,2}$ \\ ${ }^{1}$ Department of Oral Biology, School of Dental Medicine, State University of New York at Buffalo, \\ Buffalo, NY 14214 \\ ${ }^{2}$ Department of Oral Diagnostic Sciences, School of Dental Medicine, State University of New \\ York at Buffalo, Buffalo, NY 14214
}

\begin{abstract}
Sjögren's syndrome (SS) is an autoimmune disease of exocrine tissue that primarily affects women. Although patients typically experience xerostomia and xerophthalmia, numerous systemic disease manifestations are seen. Innate immune hyperactivity is integral to many autoimmune diseases, including SS. Results from SS mouse models suggest that innate immune dysregulation drives disease and this is a seminal event in SS pathogenesis. Findings in SS patients corroborate those in mouse models, as innate immune cells and pathways are dysregulated both in exocrine tissue and in peripheral blood. We will review the role of the innate immune system in SS pathogenesis. We will discuss the etiology of SS with an emphasis on innate immune dysfunction. Moreover, we will review the innate cells that mediate inflammation in SS, the pathways implicated in disease, and the potential mechanisms governing their dysregulation. Finally, we will discuss emerging therapeutic approaches to target dysregulated innate immune signaling in SS.
\end{abstract}

\section{Keywords}

Sjögren's syndrome; Innate immunity; A253; submandibular gland; toll-like receptor

\section{Introduction}

Sjögren's syndrome (SS) is a debilitating autoimmune disease in which the immune system targets exocrine gland tissue. Like many other autoimmune diseases, SS displays a strong female predilection [1]. The disease occurs in two forms: primary (pSS) and secondary (sSS). Patients with pSS often experience loss of salivary and lacrimal flow, and exhibit serious systemic disease manifestations as well [2]. In sSS, patients have a diagnosis of SS as well as another autoimmune connective tissue disease, such as lupus erythematosus (SLE) or rheumatoid arthritis (RA) [1]. Most patients with SS experience salivary hypofunction, and this can lead to rampant dental decay and difficulty in chewing and swallowing [3]. Currently, there are no approved therapies that address disease etiology and patient management is palliative.

Corresponding Author: Jill M. Kramer, DDS, PhD, State University of New York, School of Dental Medicine, Department of Oral Biology, 3435 Main Street, 211 Foster Hall, Buffalo, NY 14214, Ph: 716-829-2551, Fax: 716-829-3942, jkramer@ buffalo.edu. * Current address:

Immco Diagnostics Inc. 60 Pineview Drive, Amherst, NY 
Although the cause of SS remains poorly understood, it is characterized by exaggerated innate and adaptive immune responses. The adaptive immune system is comprised of B and $\mathrm{T}$ cells and has been studied extensively in SS $[4,5]$. B and T cells are activated pathogenically, and abnormalities in both populations are seen in glandular tissue and systemically in SS mouse models and patients [6]. Specifically, alterations in normal CD4+ T helper subset ratios are observed $[7,8]$. Activated $T$ cells produce inflammatory cytokines that drive B cell differentiation and class switching. Numerous B cells abnormalities are found in SS patients. For example, SS patients have autoantibodies with diverse specificities and are at high risk of developing $B$ cell lymphomas [4, 9-11]. Thus, the adaptive immune system is a key contributor to SS pathology.

The adaptive immune system is often activated by signals generated by the innate immune response. Innate immunity provides the "first line" of defense, and serves to recognize Pathogen-Associated Molecular Patterns (PAMPs). These microbial components are capable of eliciting rapid and robust inflammatory responses [12]. There are many different types of receptors that bind PAMPs, termed pattern recognition receptors (PRRs). Toll-like receptors (TLRs) and nucleotide-binding oligomerization domain (NOD)-like receptors (NLRs) are examples of PRRs that are activated by PAMPs [13]. Initially, it was thought that PRRs were important only in pathogen defense [14]; however, host-derived molecules can also activate innate immunity, and this is an established disease mechanism in autoimmunity [15-18]. While the innate immune system plays an important role in SS pathogenesis [19-22], the way in which it is activated is poorly understood. This review will provide an overview of the role of innate immunity in disease initiation and the specific cells and pathways that contribute to innate activation in SS. In addition, we will discuss current therapeutic approaches to mitigate activation of innate immunity.

\section{Innate immune activation in salivary tissue precedes the adaptive in SS mouse models}

Since markers of early SS disease in humans are not well defined, mouse models are instrumental in establishing early events that mediate exocrine gland dysfunction in SS [23]. Microarray studies performed on the C57BL/6.NOD-Aec1Aec2 pSS mouse model prior to lymphocytic infiltration of the submandibular gland (SMG) and lacrimal tissue identified differential expression of numerous genes associated with innate immunity [24-26]. Studies in SMG tissue from these animals revealed upregulation of TLR3, and interferon (IFN)- and apoptosis-related genes [24, 25]. In addition, several chemokines were elevated in the lacrimal gland prior to the arrival of lymphocytes, including $\mathrm{Ccl} 8$ and $\mathrm{Ccl}$. Increased expression of the B cell chemoattractant Tnfsf13 (APRIL) was also noted [26].

Since genes associated with innate immunity are dysregulated prior to the arrival of lymphocytes, these data suggest an important role for the salivary and lacrimal gland epithelium in disease development. An elegant study in $I \kappa B-\zeta$ deficient mice provides support for an initiating role of epithelium in SS, as epithelial cells in this model are crucial for the onset of inflammation in lacrimal tissue, and enhanced apoptosis in the epithelium 
precedes lymphocyte infiltration [27]. Thus, several lines of evidence suggest that pathology in the exocrine glands is initiated by innate immune dysfunction in SS.

\section{Genetic studies in pSS patients identify polymorphisms in innate immune genes}

Although there is a need for continued genetic studies in SS patients, polymorphisms in genes associated with innate immunity are identified by several groups [28-32]. There are more than 15 robust susceptibility loci identified for SS and many of these are shared with SLE [33]. Similar to SLE, patients with SS display increased expression of type I and type II IFN-regulated genes in both salivary tissue and peripheral blood [19, 30, 34-38]. While the underlying causes of IFN activation remain poorly understood, it is possible that viruses and immune complexes could induce expression of these genes [39]. Alternatively, activating mutations within genes that regulate IFN pathways themselves may contribute to the IFN gene signature observed in SS patients. One of the most definitive genome-wide association studies in pSS patients published to date identified single nucleotide polymorphisms in many IFN-inducible genes that are implicated in innate immunity, specifically HLA alleles, STAT4, IRF5, IL-12A, and TNIP1 [21]. However, the underlying genetic abnormalities that govern SS pathogenesis remain poorly understood and further work is needed to define the pathways and regulatory networks that contribute to disease.

It is important to point out that assessment of IFN gene expression and activity carries clinical significance. Studies classifying minor salivary gland tissue from pSS patients on the basis of high and low IFN activity revealed patients with high IFN activity displayed a higher prevalence of leukopenia and hyperglobulinemia. Moreover, these patients had higher anti-nuclear antibody (ANA) titers and anti-Ro (SSA) autoantibodies, and also showed higher focus scores in salivary tissue [37]. A corroborating study of monocytes from pSS patients demonstrated the presence of a type I IFN signature was associated with higher disease activity and elevated autoantibody levels [40]. Finally, expression of MxA protein in monocytes and whole blood samples was shown to be a reliable biomarker to stratify pSS patients on the basis of type I IFN activity [41]. Since approximately $60 \%$ of pSS patients exhibit a type I IFN signature and have elevated IFN activity [37, 40, 41], these data suggest that classifying patients on this basis is relevant not only for clinical trial recruitment but also for patient management decisions.

\section{Evidence for activation of innate immunity by environmental stimuli}

The innate immune system is activated by environmental insults and these likely play an important role in the initiation and progression of disease. Studies in SS patients suggest viral infection may contribute to disease initiation and chronicity, as cytomegalovirus (CMV), Epstein Barr virus (EBV), and hepatitis $\mathrm{C}$ virus (HCV) are implicated in SS pathogenesis [42-45]. Corroborating work shows that some SS patients display an IFN gene signature (vide supra), and IFNa is secreted by plasmacytoid dendritic cells (pDCs) in response to viral agonists in salivary tissue in SS [19, 39, 46, 47]. In addition, studies in mouse models provide evidence for a virally-mediated disease etiology, as mice infected with murine CMV (mCMV) or HCV $\delta$ virus develop a SS-like disease [48, 49]. Moreover, 
an elegant genetic study in mice shows salivary hypofunction is induced by type I IFN signaling [50]. Finally, administration of a synthetic analog of double-stranded RNA (dsRNA) (typically produced by viruses) exacerbates disease manifestations in SS-prone mice [51, 52]. While further studies are needed to establish the role of viral infection in SS conclusively, current evidence suggests that viruses mediate disease pathogenesis in at least a subset of patients.

\section{Innate immune cells in SS disease}

Many types of innate cells are implicated in SS. Inappropriate activation of innate immune pathways occurs within exocrine tissue as well as systemically [19, 27, 53]. DCs, macrophages, salivary epithelial gland cells (SGECs) and natural killer (NK) cells are among the best characterized innate cells in SS, and the role of these cells in disease is discussed below.

\subsection{Dendritic Cells}

DCs play an important role in SS, as they function as antigen presenting cells in ectopic germinal centers in salivary tissue [54]. Studies show DCs are decreased in peripheral blood and elevated in salivary tissue of pSS patients as compared to controls [19, 55, 56]. Evidence suggests that follicular DCs contribute to ectopic lymphoid neogenesis in salivary tissue in SS, as these cells promote expansion of $\mathrm{T}$ cells and are also associated with somatic hypermutation of B cells [57].

A specific DC subset, termed plasmacytoid DCs (pDCs), is associated with B cell infiltration in SS salivary tissue [58]. Plasmacytoid DCs are activated by TLRs and secrete numerous pro-inflammatory cytokines, including IFNa [59]. Mice injected systemically with an inflammatory stimulus exhibit salivary gland dysfunction that correlates with increased frequency of pDCs in the gland [60]. Importantly, a recent study suggests that these cells may also serve a tolerogenic role in SS, as pDCS and IFNa promote the expansion of regulatory $\mathrm{T}$ cells that have specificity for the SS autoantigen La [61]. Thus, further studies are needed to determine whether pDCs are primarily pathogenic or protective in disease.

\subsection{Macrophages}

Several studies suggest an important role for macrophages in salivary and lacrimal gland pathology. In the NOD model of SS, macrophages are recruited to salivary gland tissue prior to lymphocytes, suggesting that macrophage infiltration is an early disease event that promotes further immune cell chemotaxis [62]. Moreover, macrophages increase in salivary tissue with disease progression in SS patients [20]. Salivary gland macrophages have pathogenic potential in SS, as these cells express IL-18 and CXCL13, and patients with significant salivary macrophage infiltration tend to have enlarged salivary glands [63, 64]. In addition, many macrophage-associated genes are identified in severely inflamed salivary tissue from SS patients [65].

Of clinical importance, macrophages mediate dry eye in the Aire deficient mouse model for SS [66]. Notably, systemic macrophage depletion improves tear production in this model, demonstrating a definitive pathogenic role for these cells in disease [66]. Interestingly, IL-12 
expression by murine macrophages is enhanced by the SS autoantigen Ro52 [67]. This suggests a possible mechanism for inflammatory cytokine secretion by macrophages in SS, as Ro52 is elevated in peripheral blood from SS patients [68]. Thus, work in SS mouse models and pSS patients provides evidence that macrophages promote an inflammatory phenotype and also contribute to exocrine gland dysfunction in disease.

\subsection{Salivary Gland Epithelial Cells}

Saliva is produced within salivary acini, asymmetrical epithelial cells that are highly polarized. Cell polarity is controlled by cell-to-cell and the cell-to-extracellular matrix (ECM) interactions [69]. Decreased salivary flow is a hallmark of SS patients [2]. Studies in SS patients and mouse models suggest that this is due, at least in part, to loss of polarity in the salivary epithelium [70].

Tight junctions (TJ) mediate cell-to-cell interactions and dysregulation of salivary TJs is implicated in SS pathogenesis. TJ proteins establish a barrier between the apical and basolateral regions of the cell. In healthy individuals, TJs localize to the apical side of the epithelium. TJs are composed of complex branching networks of transmembrane proteins [71]. Claudins and occludins are $\mathrm{TJ}$ proteins that facilitate cell-to-cell interactions through their extracellular domains. TJs also require intracellular anchoring proteins such as ZO-1 [71]. In salivary tissue from SS patients, the apical localization of ZO-1 and occludin is maintained, but the expression of both is decreased. In addition, claudin proteins are redistributed to the basolateral surface, as evidence of dysregulated cell polarity [70]. Of note, the pro-inflammatory cytokines IFN $\gamma$ and tumor necrosis factor a (TNFa) induce TJ disorganization in both human and rat acinar cells that is reminiscent of that seen in SS patients $[72,73]$. Both IFN $\gamma$ and TNFa may be secreted as part of the innate immune response [74]. These data suggest that the loss of TJ integrity in salivary epithelium in SS may be mediated by innate immune activation and this likely contributes to decreased saliva production in SS patients [72].

The histopathologic hallmark of SS is the presence of periductal lymphocytic infiltrates in the salivary gland [75, 76]. Since these cells are in close proximity, interactions between the epithelium and immune cells likely contribute to disease pathogenesis. In fact, both cultured SGECs and salivary gland tissue secrete numerous inflammatory mediators and express costimulatory markers that shape the immune response, including TLRs, MHC class I and II molecules, B-cell activating factor (BAFF), IL-1, IL-6, and IL-18, TNFa [47, 75, 77]. Moreover, epithelial cell apoptosis is essential for the development of inflammation in a SS mouse model [27]. Finally, data suggest that apoptosis and necrosis of SGECs leads to a vicious cycle of aberrant immune signaling that culminates in the recruitment, activation, and differentiation of B and T cells resulting in chronic salivary inflammation [75]. Therefore, SGEC function is compromised as a result of the inflammatory milieu in SS salivary tissue and salivary epithelium itself contributes directly to the innate immune hyperactivity observed in SS. 


\subsection{Natural Killer cells}

Historically, NK cells were recognized as key mediators of anti-viral and anti-tumor responses. NK cells express TLRs and communicate with DCs in shaping adaptive immunity $[78,79]$. Emerging data show NK cells contribute to SS pathogenesis, although the precise role of these cells in disease remains unclear. Recent work using a mCMV model of SS found NK cells induced CD4+ T cell apoptosis in salivary tissue during chronic infection that was mediated by NK cell expression of TNF-related apoptosis inducing ligand (TRAIL) [80]. Subsequent experiments in TRAIL deficient mice revealed that persistent mCMV infection led to salivary gland inflammation reminiscent of SS disease. Moreover, TRAIL-/ - animals showed reduced tear and salivary flow and diminished anti-Ro autoantibodies [80]. These data suggest that NK cells play a crucial role in mitigating SS development [80].

In contrast to findings in mice, NK cells correlate with salivary gland inflammation in pSS patients [31]. NK cells express NCR3/NKp30, an activating receptor that promotes type II IFN secretion and facilitates cross talk with DCs. Genetic polymorphisms in the promoter region of NCR3/NKp30 are associated with diminished transcription and protection from pSS [31]. Importantly, NKp30 expression and activity are increased in pSS patients as compared to controls. SGECs express NKp30 ligands, activation of which causes secretion of Th1 cytokines [31]. In contrast to findings in salivary tissue, peripheral blood NK cell numbers are diminished, and NK cell killing activity and activating receptor expression is significantly reduced in pSS patients as compared to healthy controls [81].

While the reasons for the disparate findings in mouse models and pSS patients are unclear, the initiation of SS is multifactorial [6,82]. While viruses are thought to contribute to SS development, the disease etiology is complex (vide supra). It is possible that NK cells exacerbate disease in some individuals, but are protective when the disease is driven primarily by viral infection. Alternatively, NK cells may be protective in early disease and pathogenic once disease becomes advanced. Thus, further studies are needed to clarify the role of NK cells in disease initiation and progression.

\section{Mechanisms of innate immune activation in SS}

\subsection{Toll-like receptors}

TLRs are crucial for innate immune activation [14]. TLRs are upregulated in salivary tissue and peripheral blood from SS patients and mouse models [25, 77, 83-87]. Therefore, signals transduced by TLR ligation may represent a sustained event in SS pathogenesis. While several TLRs are dysregulated in SS, we will limit our discussion to those that are best characterized in this disease.

6.1.1. Cell surface TLRs: TLR2 and TLR4-TLR2 and TLR4 mediate pathology in many different autoimmune diseases, although their role in SS is incompletely understood $[17,18,88]$. Emerging evidence suggests TLR 2 and TLR4 signaling is dysregulated locally and systemically in SS. Peripheral blood mononuclear cells from SS patients stimulated with agonists for TLR2 or TLR4 (peptidoglycan (PGN) or lipopolysaccharide (LPS), respectively) secrete higher levels of the pro-inflammatory cytokine IL-17 as compared to 
those from healthy controls [85]. Moreover, both TLR2 and TLR4 transcripts are elevated in salivary tissue derived from SS mouse models and SS patients as compared to controls [77, 86], and stimulation of SGECs with LPS or PGN causes upregulation of the co-stimulatory markers ICAM-1 and MHC-1 [77].

Although TLR2 and TLR4 are functional in SGECs, key features of salivary epithelium that may contribute to SS disease have yet to be examined, including activation of specific signaling pathways and inflammatory cytokine production. It is noteworthy to mention that studies using the human submandibular gland cell line, HSG, ascribe a functional role to TLR4 [83]. However, these cells were recently determined to be a HeLa cell contaminant [89].

Therefore, we performed studies to examine the effects of TLR4 ligation on salivary cells. We sought to determine whether TLR4 was expressed and functional in the human SMG cell line A253 [90]. We examined A253 cells for expression of TLR4 and associated signaling molecules in the presence and absence of LPS stimulation. We found each of these genes are expressed constitutively and transcript levels are unchanged following LPS treatment (Figure 1A). We then assessed expression of TLR4 in A253 cells using flow cytometry. We found TLR4 is expressed on A253 cells, and stimulation with LPS causes a modest increase in surface expression (Figure 1B). We then stimulated cells for 24 hours (h) and performed western blotting for the signaling intermediate MyD88. We found MyD88 was expressed in A253 cells and expression was not affected by LPS treatment (Figure 1C). Finally, we sought to determine whether LPS activated a known downstream target of TLR4, the NFKB signaling pathway. As expected, we observed phosphorylation of NF- $\kappa \mathrm{B}$ p65 following incubation with LPS. Maximal p65 phosphorylation was observed 30 minutes post stimulation (Figure 1D). Taken together, these data show human SMG cells express TLR4 and are responsive to the classical TLR4 agonist, LPS.

To determine whether LPS induces inflammation in A253 cells, we cultured cells in the presence or absence of LPS for $24 \mathrm{~h}$. We harvested the supernatant and performed multiplex arrays for inflammatory cytokines and chemokines implicated in SS. We found A253 cells secrete IL-6, IL-12, Monocyte Chemotactic Protein-1 (MCP-1), Regulated on Activation, Normal T Expressed and Secreted (RANTES), and Granulocyte Macrophage ColonyStimulating Factor (GM-CSF) constitutively. Secretion of IL-6, IL-12, RANTES, and GMCSF was further enhanced following stimulation with LPS ( $p=0.01,0.01,0.005$, and 0.0002 , respectively) (Figure 2). Although MCP-1 was also increased following LPS stimulation, the difference was not significant $(\mathrm{p}=0.14)$. Thus, treatment of human salivary cells with LPS induces release of several inflammatory mediators that are implicated in SS pathogenesis.

Therefore, studies by our group and others show activation of TLR2 and TLR4 induces many of the same pro-inflammatory cytokines and chemokines that are upregulated in SS patients [8,91-94], and ligation these receptors likely contributes to the chronic inflammatory landscape that drives pathology in this debilitating disease. These findings are consistent with those in other autoimmune connective tissue diseases, as TLR2 and TLR4 agonism exacerbates disease in SLE, RA, and systemic sclerosis [95]. 
6.1.2. Endosomal TLRs: TLR3, TLR7, and TLR9—Several studies in mice and humans demonstrate an important role for TLR3 in SS pathogenesis. TLR3 is expressed by salivary epithelium of SS mice and healthy controls and is activated by dsRNA viruses [51]. Administration of the TLR3 agonist polyinosinic:polycytidyic acid (poly(I:C)) to SS-prone mice causes loss of salivary flow and upregulation of numerous inflammatory cytokines and chemokines, including type I IFN. Moreover, sialadenitis is increased in SS-prone mice treated with poly(I:C) as compared to controls, supporting a viral etiology for SS [51, 52] (vide supra).

Studies in human cells corroborate those in mice. TLR3 is expressed and functional in primary culture human SGECS, as stimulation of cells with the TLR3 ligand poly(I:C) causes upregulation of ICAM-1, CD40 and MHC class I [77]. Further studies using human salivary epithelium support a role for TLR3 ligation in glandular apoptosis $[84,96]$. Importantly, activation of TLR3 expressed by SGECs induces secretion of BAFF and promotes the synthesis of Ro52, an autoantigen included in the diagnostic criteria for SS [97-99]. Data from mouse models and SS patients show that both local and systemic BAFF expression is integral to SS pathogenesis. BAFF is crucial to maintain peripheral B cells and high BAFF levels allow enhanced survival of autoreactive B cells [100, 101]. The BAFF transgenic mouse model develops loss of salivary flow and salivary gland inflammation similar to SS patients [102]. Moreover, BAFF levels are elevated in pSS patients and are even higher than those observed in patients with SLE or RA [102]. Finally, evidence suggests that elevated BAFF levels contribute to loss of B cell tolerance and the development of B cell lymphomas in SS patients [103, 104].

The role of other endosomal TLRs in SS is less well understood. TLR7 and TLR9 are elevated in SS salivary tissue [87]. A recent study found that there are no differences in B cell expression of TLR7 and TLR9 between SS patients and healthy controls [105]. However, B cells from pSS patients secrete increased amounts of several pro-inflammatory cytokines when stimulated with agonists for TLR7 or TLR9, suggesting that TLR signaling in B cells may contribute to the chronic inflammatory landscape observed [106]. Interestingly, a recent study found that when pSS patients were segregated on the basis of type I IFN expression, pDCs and monocytes from the IFN-expressing subset expressed elevated levels of TLR7, whereas IFN negative patients expressed normal levels of TLR7 [107]. Thus, these studies suggest that endosomal TLRs contribute to SS and may be particularly important in IFN positive patients, although further work is required to understand the way in which TLR signaling pathways mediate pathology in SS.

6.1.3. Activation of TLRs in SS-Although TLRs are upregulated in salivary tissue from SS patients and mouse models [25, 77, 83-87], it is not clear whether TLR activation occurs as a result of endogenous or exogenous triggers, and whether these are produced within exocrine tissue or are expressed systemically. Because high rates of chronic bacterial infection are not reported for the adult SS population, it is unlikely that the ligands that activate TLRs in SS are primarily pathogen-derived. Thus, it is probable that alternative mechanisms drive TLR activation in SS, such as sterile inflammation mediated by hostderived ligands. 
These endogenous ligands, termed damage or danger-associated molecular patterns (DAMPs), include heat shock and ECM proteins [108]. Inflammation caused by DAMPs is considered to be "sterile," because it arises as a result of tissue damage and is independent of microbial infection $[108,109]$. Molecules that serve as DAMPs are normally sequestered from the immune system. However, when tissue integrity is compromised they are released in soluble form, thereby allowing for TLR engagement. Numerous studies show activation of TLRs by DAMPs has pathologic consequence in autoimmunity [95]. Specifically, the ECM molecules biglycan and tenascin-c are implicated in SLE and RA pathogenesis, respectively $[16,18]$. While DAMP-mediated inflammation is not well studied in SS, it is likely an important driver of inflammation [110]. The ECM molecules laminin, fibronectin, and heparin sulfate are dysregulated in SS salivary tissue, which may result in heightened TLR signaling $[25,111,112]$. Thus DAMP-induced inflammation may contribute to innate immune activation that is characteristic of SS [110].

\subsection{Inflammasome-mediated inflammation}

The inflammasome is a key component of the innate immune system. Inflammasomes are activated by microbial components, toxins, and mediators that are released following cellular damage [113]. Inflammasome assembly is dependent on NLR family members [114]. There are several types of inflammasomes that are named according to the specific NLR protein utilized, such NLRP1, NLRP3, and AIM2 [115]. Upon ligation, inflammasomes activate caspase proteins, ultimately culminating in the secretion of IL-1 and IL-18 [115]. Of significance to SS pathogenesis, the NLRP3 inflammasome is activated by concomitant stimulation of TLRs and purinergic $\mathrm{P} 2 \mathrm{X}_{4} / \mathrm{P} 2 \mathrm{X}_{7}$ receptors [15]. Inflammasome-related genes are elevated in human SS salivary tissue, including P2 $\mathrm{X}_{7}$, NLRP3 and caspase-1, and this expression correlates with focal lymphocytic sialadenitis and the presence of anti-Ro autoantibodies [116]. Corroborative studies in SS mouse models show capase-1 is elevated and active in SS salivary tissue in early disease $[25,117]$. Both IL-1 and IL-18 are upregulated in murine and human SS, indicating possible inflammasome hyperactivity in disease $[25,63,116,118-121]$. Finally, studies in $P 2 X_{7}$ receptor $\left(P 2 X_{7} R\right)$ deficient mice show that these animals are protected from salivary inflammation, and local delivery of a $\mathrm{P} 2 \mathrm{X}_{7} \mathrm{R}$ agonist to $P 2 X_{7} R$ sufficient mice induces salivary inflammation [122]. Taken together, these studies suggest that inflammasome activation in salivary tissue may be a key event in SS pathogenesis.

\subsection{Noncoding RNAs}

Emerging evidence supports a role for noncoding RNAs in SS, as both short and long noncoding RNAs (lncRNAs) are potent regulators of innate immunity [123, 124]. LncRNAs function at every level of gene regulation [125, 126], and are implicated in many different pathoses ranging from autoimmunity to cancer [127, 128]. LncRNAs regulate many aspects of innate immunity including cytokine and chemokine expression, apoptosis, and antigen presentation [129]. While the role of lncRNAs in SS is largely speculative at present, a recent study profiled these RNAs in the salivary tissue of pSS patients and healthy controls. This study identified more than 1000 lncRNAs that were differentially expressed in pSS salivary tissue. Of note, expression of specific lncRNAs showed strong correlations with SS disease manifestations including the presence of rheumatoid factor (RF), anti-La (SSB) 
autoantibodies, immunoglobulin (Ig) A, and IgM titers [130], suggesting a pathogenic role for certain lncRNAs in disease.

MicroRNAs (miRNAs) are short non-coding RNAs that play important regulatory roles in post-transcriptional gene expression. They act by inhibiting gene expression or by promoting gene degradation [131]. It is estimated that miRNAs regulate between 30 and $90 \%$ of genes in the genome, as a single miRNA may regulate hundreds of genes [132, 133]. Aberrant miRNA expression is implicated in numerous autoimmune diseases including SS [132-136].

A study using minor salivary gland tissue from pSS patients identified miRNAs that are strongly associated with sialadenitis [134]. Significantly, this study revealed 9 miRNAs that are differentially expressed in pSS patients with reduced salivary production [134]. More recent work shows several miRNAs are increased in minor salivary gland tissue, SGECs, monocytes and peripheral blood mononuclear cells from SS patients [137-142]. Importantly, several studies suggest miRNAs contribute to innate immune dysregulation in SS, as numerous miRNAs are elevated in monocytes derived from SS patients as compare to controls and miRNA-target pathway predictions suggest these may suppress TGF $\beta$ signaling [142]. Moreover, the miRNA MiR-146a shows increased expression in both glandular tissue and peripheral blood mononuclear cells of SS patients, and overexpression of MiR-146a in the human monocyte cell line THP-1 diminishes pro-inflammatory cytokine secretion, suggesting a possible regulatory role for this miRNA in SS pathogenesis [137]. Thus, while studies point to a functional role for noncoding RNAs in disease pathogenesis, further work is needed to determine the means by which these regulate the innate immune response in SS.

\section{Therapeutic Approaches Targeting Innate Immunity May Be Efficacious}

Many therapeutics that reduce activation of the innate immune response are currently in clinical trials for the treatment of RA, SLE, and inflammatory bowel disease (IBD) [95, 108, 143-145]. A summary of emerging innate immune drug targets, effects and study phase is provided in Table 1 [95, 144, 146-158]. Given the centrality of innate-driven inflammation in SS, inhibition of receptors and pathways that mediate this dysregulation may constitute a successful strategy to reduce local and systemic pathology in this disease.

Inhibition of TLR-mediated activation holds therapeutic promise, as drugs that target TLR2 and TLR4 directly are in clinical trials for several autoimmune diseases [95]. In addition, blockade of TLR signaling intermediates show promise for the treatment of RA and IBD [108]. These drugs may also be efficacious in the treatment of SS, as these receptors and pathways are implicated in both local and systemic disease ([77, 85] and Figure 2). Therefore, targeting of TLRs may prevent progressive systemic inflammation and preserve glandular function.

Blockade of cytokines generated by innate immune interactions may also mitigate SS disease manifestations. While pSS patients commonly experience salivary and lacrimal dysfunction, fatigue is also a common disease manifestation [159]. Importantly, a recent randomized clinical trial examined the effect of IL-1 inhibition on fatigue in 26 patients with pSS. While this study did not achieve its primary endpoint, more patients that received IL-1 
blockade saw a 50\% reduction in fatigue as compared to those that received the placebo [156], suggesting inhibition of IL-1 may be beneficial in SS. Moreover, studies are ongoing to evaluate the efficacy of IL-6 and BAFF inhibition in pSS patients [152]. Given the importance of these cytokines in B cell maturation and survival [100, 101, 160], inhibition of such may diminish pathogenic autoantibody production and may even reduce malignant transformation of autoreactive B cells.

While systemic administration of drugs that inhibit innate immune activation may be necessary for some patients with SS, local delivery of therapeutics directly to the salivary tissue may be beneficial for others. Systemic drug administration will likely reduce inflammation, but will also attenuate the host response to pathogens. Therefore, local delivery of drugs may be advantageous, as the salivary tissue could be targeted without widespread immunosuppression. Accordingly, salivary duct cannulation is an efficacious approach in animal models and further studies are needed to determine whether this approach is feasible for SS patients [161, 162]. Thus, therapeutics that target local or systemic innate immune hyperactivity will likely result in improved patient management and amelioration of SS disease.

\section{Conclusion}

In summary, the innate immune response is crucial for SS pathogenesis, as it is implicated in disease initiation, chronicity, and likely contributes to the development of B cell lymphomas. Numerous cell types in peripheral blood as well as in exocrine tissue participate in the hyperactive innate immune response in SS. Emerging data suggest that noncoding RNAs also mediate innate immune dysfunction in the context of SS. Therefore, therapeutics that target innate immune inflammation will likely prove an effective therapeutic strategy for patients afflicted with this debilitating disease.

\section{Acknowledgments}

Funding for this study was provided by the University at Buffalo School of Dental Medicine Start-up Funds (JMK).

\section{Abbreviations}

$\begin{array}{ll}\text { ANA } & \text { Anti-nuclear antibodies } \\ \text { BAFF } & \text { B-cell activating factor } \\ \text { CMV } & \text { Cytomegalovirus } \\ \text { DAMP } & \text { Damage or danger-associated molecular pattern } \\ \text { DC } & \text { Dendritic cell } \\ \text { EBV } & \text { Epstein Barr virus } \\ \text { ECM } & \text { Extracellular matrix } \\ \text { HCV } & \text { Hepatitis C virus }\end{array}$




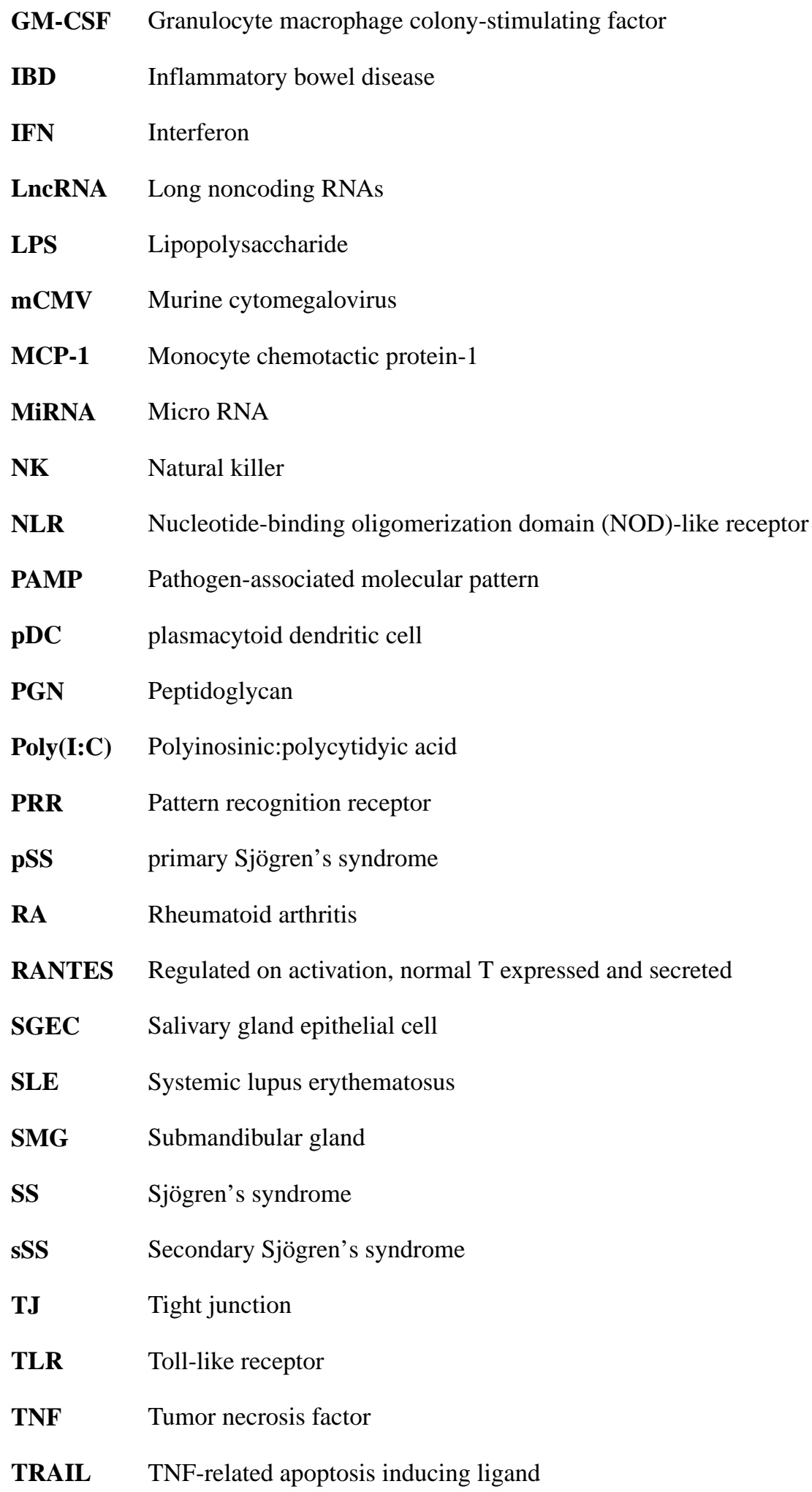




\section{References}

1. Helmick CG, Felson DT, Lawrence RC, Gabriel S, Hirsch R, Kwoh CK, Liang MH, Kremers HM, Mayes MD, Merkel PA, Pillemer SR, Reveille JD, Stone JH, N.A.D. Workgroup. Estimates of the prevalence of arthritis and other rheumatic conditions in the United States. Part I. Arthritis Rheum. 2008; 58:15-25. [PubMed: 18163481]

2. Malladi AS, Sack KE, Shiboski SC, Shiboski CH, Baer AN, Banushree R, Dong Y, Helin P, Kirkham BW, Li M, Sugai S, Umehara H, Vivino FB, Vollenweider CF, Zhang W, Zhao Y, Greenspan JS, Daniels TE, Criswell LA. Primary Sjogren's syndrome as a systemic disease: a study of participants enrolled in an international Sjogren's syndrome registry. Arthritis care \& research. 2012; 64:911-918. [PubMed: 22238244]

3. Kramer JM. Current concepts in Sjogren's syndrome and considerations for the dental practitioner. The New York state dental journal. 2015; 81:24-29.

4. Hansen A, Lipsky PE, Dörner T. B cells in Sjögren's syndrome: indications for disturbed selection and differentiation in ectopic lymphoid tissue. Arthritis Res Ther. 2007; 9:218. [PubMed: 17697366]

5. Ambrosi A, Wahren-Herlenius M. Update on the immunobiology of Sjogren's syndrome. Curr Opin Rheumatol. 2015; 27:468-475. [PubMed: 26108063]

6. Mavragani CP, Moutsopoulos HM. Sjogren's syndrome. Annual review of pathology. 2014; 9:273285.

7. Mitsias DI, Tzioufas AG, Veiopoulou C, Zintzaras E, Tassios IK, Kogopoulou O, Moutsopoulos HM, Thyphronitis G. The Th1/Th2 cytokine balance changes with the progress of the immunopathological lesion of Sjogren's syndrome. Clin Exp Immunol. 2002; 128:562-568. [PubMed: 12067313]

8. Katsifis GE, Moutsopoulos NM, Wahl SM. T lymphocytes in Sjogren's syndrome: contributors to and regulators of pathophysiology. Clin Rev Allergy Immunol. 2007; 32:252-264. [PubMed: 17992592]

9. Ekström Smedby K, Vajdic CM, Falster M, Engels EA, Martínez-Maza O, Turner J, Hjalgrim H, Vineis P, Seniori Costantini A, Bracci PM, Holly EA, Willett E, Spinelli JJ, La Vecchia C, Zheng T, Becker N, De Sanjosé S, Chiu BC, Dal Maso L, Cocco P, Maynadié M, Foretova L, Staines A, Brennan P, Davis S, Severson R, Cerhan JR, Breen EC, Birmann B, Grulich AE, Cozen W. Autoimmune disorders and risk of non-Hodgkin lymphoma subtypes: a pooled analysis within the InterLymph Consortium. Blood. 2008; 111:4029-4038. [PubMed: 18263783]

10. Hansen A, Gosemann M, Pruss A, Reiter K, Ruzickova S, Lipsky PE, Dörner T. Abnormalities in peripheral B cell memory of patients with primary Sjögren's syndrome. Arthritis Rheum. 2004; 50:1897-1908. [PubMed: 15188366]

11. Hansen A, Jacobi A, Pruss A, Kaufmann O, Scholze J, Lipsky PE, Dörner T. Comparison of immunoglobulin heavy chain rearrangements between peripheral and glandular B cells in a patient with primary Sjögren's syndrome. Scand J Immunol. 2003; 57:470-479. [PubMed: 12753504]

12. Kawai T, Akira S. Toll-like receptors and their crosstalk with other innate receptors in infection and immunity. Immunity. 2011; 34:637-650. [PubMed: 21616434]

13. Liu J, Cao X. Cellular and molecular regulation of innate inflammatory responses. Cellular \& molecular immunology. 2016; 13:711-721. [PubMed: 27818489]

14. Medzhitov R, Janeway C Jr. The Toll receptor family and microbial recognition. Trends in microbiology. 2000; 8:452-456. [PubMed: 11044679]

15. Babelova A, Moreth K, Tsalastra-Greul W, Zeng-Brouwers J, Eickelberg O, Young MF, Bruckner P, Pfeilschifter J, Schaefer RM, Gröne HJ, Schaefer L. Biglycan, a danger signal that activates the NLRP3 inflammasome via toll-like and P2X receptors. J Biol Chem. 2009; 284:24035-24048. [PubMed: 19605353]

16. Moreth K, Brodbeck R, Babelova A, Gretz N, Spieker T, Zeng-Brouwers J, Pfeilschifter J, Young MF, Schaefer RM, Schaefer L. The proteoglycan biglycan regulates expression of the B cell chemoattractant CXCL13 and aggravates murine lupus nephritis. J Clin Invest. 2010; 120:42514272. [PubMed: 21084753] 
17. Bhattacharyya S, Tamaki Z, Wang W, Hinchcliff M, Hoover P, Getsios S, White ES, Varga J. FibronectinEDA promotes chronic cutaneous fibrosis through Toll-like receptor signaling. Science translational medicine. 2014; 6:232ra250.

18. Midwood K, Sacre S, Piccinini AM, Inglis J, Trebaul A, Chan E, Drexler S, Sofat N, Kashiwagi M, Orend G, Brennan F, Foxwell B. Tenascin-C is an endogenous activator of Toll-like receptor 4 that is essential for maintaining inflammation in arthritic joint disease. Nat Med. 2009; 15:774-780. [PubMed: 19561617]

19. Gottenberg JE, Cagnard N, Lucchesi C, Letourneur F, Mistou S, Lazure T, Jacques S, Ba N, Ittah M, Lepajolec C, Labetoulle M, Ardizzone M, Sibilia J, Fournier C, Chiocchia G, Mariette X. Activation of IFN pathways and plasmacytoid dendritic cell recruitment in target organs of primary Sjögren's syndrome. Proc Natl Acad Sci U S A. 2006; 103:2770-2775. [PubMed: 16477017]

20. Christodoulou MI, Kapsogeorgou EK, Moutsopoulos HM. Characteristics of the minor salivary gland infiltrates in Sjögren's syndrome. J Autoimmun. 2010; 34:400-407. [PubMed: 19889514]

21. Lessard CJ, Li H, Adrianto I, Ice JA, Rasmussen A, Grundahl KM, Kelly JA, Dozmorov MG, Miceli-Richard C, Bowman S, Lester S, Eriksson P, Eloranta ML, Brun JG, Goransson LG, Harboe E, Guthridge JM, Kaufman KM, Kvarnstrom M, Jazebi H, Cunninghame Graham DS, Grandits ME, Nazmul-Hossain AN, Patel K, Adler AJ, Maier-Moore JS, Farris AD, Brennan MT, Lessard JA, Chodosh J, Gopalakrishnan R, Hefner KS, Houston GD, Huang AJ, Hughes PJ, Lewis DM, Radfar L, Rohrer MD, Stone DU, Wren JD, Vyse TJ, Gaffney PM, James JA, Omdal R, Wahren-Herlenius M, Illei GG, Witte T, Jonsson R, Rischmueller M, Ronnblom L, Nordmark G, Ng WF, Registry UKPSsS, Mariette X, Anaya JM, Rhodus NL, Segal BM, Scofield RH, Montgomery CG, Harley JB, Sivils KL. Variants at multiple loci implicated in both innate and adaptive immune responses are associated with Sjogren's syndrome. Nat Genet. 2013; 45:12841292. [PubMed: 24097067]

22. Low HZ, Witte T. Aspects of innate immunity in Sjögren's syndrome. Arthritis Res Ther. 2011; 13:218. [PubMed: 21635716]

23. Lavoie TN, Lee BH, Nguyen CQ. Current concepts: mouse models of Sjögren's syndrome. J Biomed Biotechnol. 2011; 2011:549107. [PubMed: 21253584]

24. Nguyen CQ, Sharma A, Lee BH, She JX, McIndoe RA, Peck AB. Differential gene expression in the salivary gland during development and onset of xerostomia in Sjögren's syndrome-like disease of the C57BL/6.NOD-Aec1Aec2 mouse. Arthritis Res Ther. 2009; 11:R56. [PubMed: 19379516]

25. Killedar SJ, Eckenrode SE, McIndoe RA, She JX, Nguyen CQ, Peck AB, Cha S. Early pathogenic events associated with Sjogren's syndrome $(\mathrm{SjS})$-like disease of the NOD mouse using microarray analysis. Laboratory investigation; a journal of technical methods and pathology. 2006; 86:12431260. [PubMed: 17075579]

26. Nguyen CQ, Sharma A, She JX, McIndoe RA, Peck AB. Differential gene expressions in the lacrimal gland during development and onset of keratoconjunctivitis sicca in Sjogren's syndrome (SJS)-like disease of the C57BL/6.NOD-Aec1Aec2 mouse. Exp Eye Res. 2009; 88:398-409. [PubMed: 19103199]

27. Okuma A, Hoshino K, Ohba T, Fukushi S, Aiba S, Akira S, Ono M, Kaisho T, Muta T. Enhanced Apoptosis by Disruption of the STAT3-IкB- $\zeta$ Signaling Pathway in Epithelial Cells Induces Sjögren's Syndrome-like Autoimmune Disease. Immunity. 2013

28. Ice JA, Li H, Adrianto I, Lin PC, Kelly JA, Montgomery CG, Lessard CJ, Moser KL. Genetics of Sjögren's syndrome in the genome-wide association era. J Autoimmun. 2012

29. Segal BM, Nazmul-Hossain AN, Patel K, Hughes P, Moser KL, Rhodus NL. Genetics and genomics of Sjogren's syndrome: research provides clues to pathogenesis and novel therapies. Oral Surg Oral Med Oral Pathol Oral Radiol Endod. 2011; 111:673-680. [PubMed: 21497524]

30. Emamian ES, Leon JM, Lessard CJ, Grandits M, Baechler EC, Gaffney PM, Segal B, Rhodus NL, Moser KL. Peripheral blood gene expression profiling in Sjögren's syndrome. Genes Immun. 2009; 10:285-296. [PubMed: 19404300]

31. Rusakiewicz S, Nocturne G, Lazure T, Semeraro M, Flament C, Caillat-Zucman S, Sene D, Delahaye N, Vivier E, Chaba K, Poirier-Colame V, Nordmark G, Eloranta ML, Eriksson P, Theander E, Forsblad-d'Elia H, Omdal R, Wahren-Herlenius M, Jonsson R, Ronnblom L, Nititham J, Taylor KE, Lessard CJ, Sivils KL, Gottenberg JE, Criswell LA, Miceli-Richard C, Zitvogel L, 
Mariette X. NCR3/NKp30 contributes to pathogenesis in primary Sjogren's syndrome. Science translational medicine. 2013; 5:195ra196.

32. Musone SL, Taylor KE, Nititham J, Chu C, Poon A, Liao W, Lam ET, Ma A, Kwok PY, Criswell LA. Sequencing of TNFAIP3 and association of variants with multiple autoimmune diseases. Genes Immun. 2011; 12:176-182. [PubMed: 21326317]

33. Teruel M, Alarcon-Riquelme ME. Genetics of systemic lupus erythematosus and Sjogren's syndrome: an update. Curr Opin Rheumatol. 2016

34. Båve U, Nordmark G, Lövgren T, Rönnelid J, Cajander S, Eloranta ML, Alm GV, Rönnblom L. Activation of the type I interferon system in primary Sjögren's syndrome: a possible etiopathogenic mechanism. Arthritis Rheum. 2005; 52:1185-1195. [PubMed: 15818675]

35. Hjelmervik TO, Petersen K, Jonassen I, Jonsson R, Bolstad AI. Gene expression profiling of minor salivary glands clearly distinguishes primary Sjögren's syndrome patients from healthy control subjects. Arthritis Rheum. 2005; 52:1534-1544. [PubMed: 15880807]

36. Perez P, Anaya JM, Aguilera S, Urzua U, Munroe D, Molina C, Hermoso MA, Cherry JM, Alliende C, Olea N, Ruiz-Narvaez E, Gonzalez MJ. Gene expression and chromosomal location for susceptibility to Sjogren's syndrome. J Autoimmun. 2009; 33:99-108. [PubMed: 19523788]

37. Hall JC, Baer AN, Shah AA, Criswell LA, Shiboski CH, Rosen A, Casciola-Rosen L. Molecular Subsetting of Interferon Pathways in Sjogren's Syndrome. Arthritis \& rheumatology. 2015; 67:2437-2446. [PubMed: 25988820]

38. Hall JC, Casciola-Rosen L, Berger AE, Kapsogeorgou EK, Cheadle C, Tzioufas AG, Baer AN, Rosen A. Precise probes of type II interferon activity define the origin of interferon signatures in target tissues in rheumatic diseases. Proc Natl Acad Sci U S A. 2012; 109:17609-17614. [PubMed: 23045702]

39. Li H, Ice JA, Lessard CJ, Sivils KL. Interferons in Sjögren's Syndrome: Genes, Mechanisms, and Effects. Front Immunol. 2013; 4:290. [PubMed: 24062752]

40. Brkic Z, Maria NI, van Helden-Meeuwsen CG, van de Merwe JP, van Daele PL, Dalm VA, Wildenberg ME, Beumer W, Drexhage HA, Versnel MA. Prevalence of interferon type I signature in CD14 monocytes of patients with Sjogren's syndrome and association with disease activity and BAFF gene expression. Ann Rheum Dis. 2012

41. Maria NI, Brkic Z, Waris M, van Helden-Meeuwsen CG, Heezen K, van de Merwe JP, van Daele PL, Dalm VA, Drexhage HA, Versnel MA. MxA as a clinically applicable biomarker for identifying systemic interferon type I in primary Sjogren's syndrome. Ann Rheum Dis. 2014; 73:1052-1059. [PubMed: 23831963]

42. Kivity S, Arango MT, Ehrenfeld M, Tehori O, Shoenfeld Y, Anaya JM, Agmon-Levin N. Infection and autoimmunity in Sjogren's syndrome: a clinical study and comprehensive review. J Autoimmun. 2014; 51:17-22. [PubMed: 24637076]

43. Yeh CC, Wang WC, Wu CS, Sung FC, Su CT, Shieh YH, Chang SN, Su FH. Correction: Association of Sjogren's Syndrome in Patients with Chronic Hepatitis Virus Infection: A Population-Based Analysis. PLoS One. 2016; 11:e0164911. [PubMed: 27749926]

44. Croia C, Astorri E, Murray-Brown W, Willis A, Brokstad KA, Sutcliffe N, Piper K, Jonsson R, Tappuni AR, Pitzalis C, Bombardieri M. Implication of Epstein-Barr virus infection in diseasespecific autoreactive B cell activation in ectopic lymphoid structures of Sjogren's syndrome. Arthritis \& rheumatology. 2014; 66:2545-2557. [PubMed: 24891330]

45. Yamazaki M, Kitamura R, Kusano S, Eda H, Sato S, Okawa-Takatsuji M, Aotsuka S, Yanagi K. Elevated immunoglobulin $\mathrm{G}$ antibodies to the proline-rich amino-terminal region of Epstein-Barr virus nuclear antigen-2 in sera from patients with systemic connective tissue diseases and from a subgroup of Sjogren's syndrome patients with pulmonary involvements. Clin Exp Immunol. 2005; 139:558-568. [PubMed: 15730403]

46. Ittah M, Miceli-Richard C, Gottenberg JE, Sellam J, Lepajolec C, Mariette X. B-cell-activating factor expressions in salivary epithelial cells after dsRNA virus infection depends on RNAactivated protein kinase activation. Eur J Immunol. 2009; 39:1271-1279. [PubMed: 19337998]

47. Ittah M, Miceli-Richard C, Eric Gottenberg J, Lavie F, Lazure T, Ba N, Sellam J, Lepajolec C, Mariette X. B cell-activating factor of the tumor necrosis factor family (BAFF) is expressed under 
stimulation by interferon in salivary gland epithelial cells in primary Sjogren's syndrome. Arthritis Res Ther. 2006; 8:R51. [PubMed: 16507175]

48. Ohyama Y, Carroll VA, Deshmukh U, Gaskin F, Brown MG, Fu SM. Severe focal sialadenitis and dacryoadenitis in NZM2328 mice induced by MCMV: a novel model for human Sjogren's syndrome. J Immunol. 2006; 177:7391-7397. [PubMed: 17082658]

49. Weller ML, Gardener MR, Bogus ZC, Smith MA, Astorri E, Michael DG, Michael DA, Zheng C, Burbelo PD, Lai Z, Wilson PA, Swaim W, Handelman B, Afione SA, Bombardieri M, Chiorini JA. Hepatitis Delta Virus Detected in Salivary Glands of Sjogren's Syndrome Patients and Recapitulates a Sjogren's Syndrome-Like Phenotype in Vivo. Pathog Immun. 2016; 1:12-40. [PubMed: 27294212]

50. Nandula SR, Dey P, Corbin KL, Nunemaker CS, Bagavant H, Deshmukh US. Salivary gland hypofunction induced by activation of innate immunity is dependent on type I interferon signaling. J Oral Pathol Med. 2013; 42:66-72. [PubMed: 22672212]

51. Deshmukh US, Nandula SR, Thimmalapura PR, Scindia YM, Bagavant H. Activation of innate immune responses through Toll-like receptor 3 causes a rapid loss of salivary gland function. $\mathrm{J}$ Oral Pathol Med. 2009; 38:42-47. [PubMed: 19192049]

52. Nandula SR, Scindia YM, Dey P, Bagavant H, Deshmukh US. Activation of innate immunity accelerates sialoadenitis in a mouse model for Sjögren's syndrome-like disease. Oral Dis. 2011; 17:801-807. [PubMed: 21815968]

53. Wildenberg ME, van Helden-Meeuwsen CG, van de Merwe JP, Drexhage HA, Versnel MA. Systemic increase in type I interferon activity in Sjögren's syndrome: a putative role for plasmacytoid dendritic cells. Eur J Immunol. 2008; 38:2024-2033. [PubMed: 18581327]

54. Bombardieri M, Pitzalis C. Ectopic lymphoid neogenesis and lymphoid chemokines in Sjogren's syndrome: at the interplay between chronic inflammation, autoimmunity and lymphomagenesis. Curr Pharm Biotechnol. 2012; 13:1989-1996. [PubMed: 22208651]

55. Ozaki Y, Ito T, Son Y, Amuro H, Shimamoto K, Sugimoto H, Katashiba Y, Ogata M, Miyamoto R, Murakami N, Amakawa R, Fukuhara S. Decrease of blood dendritic cells and increase of tissueinfiltrating dendritic cells are involved in the induction of Sjogren's syndrome but not in the maintenance. Clin Exp Immunol. 2010; 159:315-326. [PubMed: 20015272]

56. Wildenberg ME, Welzen-Coppens JM, van Helden-Meeuwsen CG, Bootsma H, Vissink A, van Rooijen N, van de Merwe JP, Drexhage HA, Versnel MA. Increased frequency of CD16+ monocytes and the presence of activated dendritic cells in salivary glands in primary Sjogren syndrome. Ann Rheum Dis. 2009; 68:420-426. [PubMed: 18397959]

57. Bombardieri M, Barone F, Humby F, Kelly S, McGurk M, Morgan P, Challacombe S, De Vita S, Valesini G, Spencer J, Pitzalis C. Activation-induced cytidine deaminase expression in follicular dendritic cell networks and interfollicular large B cells supports functionality of ectopic lymphoid neogenesis in autoimmune sialoadenitis and MALT lymphoma in Sjogren's syndrome. J Immunol. 2007; 179:4929-4938. [PubMed: 17878393]

58. Zhao J, Kubo S, Nakayamada S, Shimajiri S, Zhang X, Yamaoka K, Tanaka Y. Association of plasmacytoid dendritic cells with B cell infiltration in minor salivary glands in patients with Sjogren's syndrome. Modern rheumatology / the Japan Rheumatism Association. 2016; 26:716724.

59. Vogelsang P, Jonsson MV, Dalvin ST, Appel S. Role of dendritic cells in Sjogren's syndrome. Scand J Immunol. 2006; 64:219-226. [PubMed: 16918690]

60. Deshmukh US, Ohyama Y, Bagavant H, Guo X, Gaskin F, Fu SM. Inflammatory stimuli accelerate Sjogren's syndrome-like disease in $(\mathrm{NZB} \times \mathrm{NZW}) \mathrm{F} 1$ mice. Arthritis Rheum. 2008; 58:1318-1323. [PubMed: 18438852]

61. Pan ZJ, Horton CG, Lawrence C, Farris AD. Plasmacytoid dendritic cells and type 1 interferon promote peripheral expansion of forkhead box protein 3(+) regulatory $\mathrm{T}$ cells specific for the ubiquitous RNA-binding nuclear antigen La/Sjogren's syndrome (SS)-B. Clin Exp Immunol. 2016; 186:18-29. [PubMed: 27227559]

62. Roescher N, Lodde BM, Vosters JL, Tak PP, Catalan MA, Illei GG, Chiorini JA. Temporal changes in salivary glands of non-obese diabetic mice as a model for Sjogren's syndrome. Oral Dis. 2012; 18:96-106. [PubMed: 21914088] 
63. Manoussakis MN, Boiu S, Korkolopoulou P, Kapsogeorgou EK, Kavantzas N, Ziakas P, Patsouris E, Moutsopoulos HM. Rates of infiltration by macrophages and dendritic cells and expression of interleukin-18 and interleukin-12 in the chronic inflammatory lesions of Sjogren's syndrome: correlation with certain features of immune hyperactivity and factors associated with high risk of lymphoma development. Arthritis Rheum. 2007; 56:3977-3988. [PubMed: 18050195]

64. Kramer JM, Klimatcheva E, Rothstein TL. CXCL13 is elevated in Sjogren's syndrome in mice and humans and is implicated in disease pathogenesis. Journal of leukocyte biology. 2013; 94:10791089. [PubMed: 23904442]

65. Greenwell-Wild T, Moutsopoulos NM, Gliozzi M, Kapsogeorgou E, Rangel Z, Munson PJ, Moutsopoulos HM, Wahl SM. Chitinases in the salivary glands and circulation of patients with Sjogren's syndrome: macrophage harbingers of disease severity. Arthritis Rheum. 2011; 63:31033115. [PubMed: 21618203]

66. Zhou D, Chen YT, Chen F, Gallup M, Vijmasi T, Bahrami AF, Noble LB, van Rooijen N, McNamara NA. Critical Involvement of Macrophage Infiltration in the Development of Sjögren's Syndrome-Associated Dry Eye. Am J Pathol. 2012; 181:753-760. [PubMed: 22770665]

67. Kong HJ, Anderson DE, Lee CH, Jang MK, Tamura T, Tailor P, Cho HK, Cheong J, Xiong H, Morse HC 3rd, Ozato K. Cutting edge: autoantigen Ro52 is an interferon inducible E3 ligase that ubiquitinates IRF-8 and enhances cytokine expression in macrophages. J Immunol. 2007; 179:2630. [PubMed: 17579016]

68. Espinosa A, Zhou W, Ek M, Hedlund M, Brauner S, Popovic K, Horvath L, Wallerskog T, Oukka M, Nyberg F, Kuchroo VK, Wahren-Herlenius M. The Sjogren's syndrome-associated autoantigen Ro52 is an E3 ligase that regulates proliferation and cell death. J Immunol. 2006; 176:6277-6285. [PubMed: 16670339]

69. Coopman P, Djiane A. Adherens Junction and E-Cadherin complex regulation by epithelial polarity. Cellular and Molecular Life Sciences. 2016; 73:3535-3553. [PubMed: 27151512]

70. Barrera MJ, Bahamondes V, Sepulveda D, Quest AF, Castro I, Cortes J, Aguilera S, Urzua U, Molina C, Perez P, Ewert P, Alliende C, Hermoso MA, Gonzalez S, Leyton C, Gonzalez MJ. Sjogren's syndrome and the epithelial target: a comprehensive review. Journal of autoimmunity. 2013; 42:7-18. [PubMed: 23497939]

71. Van Itallie CM, Anderson JM. Architecture of tight junctions and principles of molecular composition. Semin Cell Dev Biol. 2014; 36:157-165. [PubMed: 25171873]

72. Baker OJ, Camden JM, Redman RS, Jones JE, Seye CI, Erb L, Weisman GA. Proinflammatory cytokines tumor necrosis factor-alpha and interferon-gamma alter tight junction structure and function in the rat parotid gland Par-C10 cell line. American journal of physiology. Cell physiology. 2008; 295:C1191-1201. [PubMed: 18768927]

73. Ewert P, Aguilera S, Alliende C, Kwon YJ, Albornoz A, Molina C, Urzua U, Quest AF, Olea N, Perez P, Castro I, Barrera MJ, Romo R, Hermoso M, Leyton C, Gonzalez MJ. Disruption of tight junction structure in salivary glands from Sjogren's syndrome patients is linked to proinflammatory cytokine exposure. Arthritis and rheumatism. 2010; 62:1280-1289. [PubMed: 20131287]

74. Moretti J, Blander JM. Cell-autonomous stress responses in innate immunity. Journal of Leukocyte Biology. 2016

75. Manoussakis MN, Kapsogeorgou EK. The role of intrinsic epithelial activation in the pathogenesis of Sjogren's syndrome. Journal of autoimmunity. 2010; 35:219-224. [PubMed: 20685080]

76. Daniels TE, Cox D, Shiboski CH, Schiødt M, Wu A, Lanfranchi H, Umehara H, Zhao Y, Challacombe S, Lam MY, De Souza Y, Schiødt J, Holm H, Bisio PA, Gandolfo MS, Sawaki T, Li M, Zhang W, Varghese-Jacob B, Ibsen P, Keszler A, Kurose N, Nojima T, Odell E, Criswell LA, Jordan R, Greenspan JS, S.s.I.C.C.A.R. Groups. Associations between salivary gland histopathologic diagnoses and phenotypic features of Sjögren's syndrome among 1,726 registry participants. Arthritis Rheum. 2011; 63:2021-2030. [PubMed: 21480190]

77. Spachidou MP, Bourazopoulou E, Maratheftis CI, Kapsogeorgou EK, Moutsopoulos HM, Tzioufas AG, Manoussakis MN. Expression of functional Toll-like receptors by salivary gland epithelial cells: increased mRNA expression in cells derived from patients with primary Sjögren's syndrome. Clin Exp Immunol. 2007; 147:497-503. [PubMed: 17302899] 
78. Hamerman JA, Ogasawara K, Lanier LL. NK cells in innate immunity. Curr Opin Immunol. 2005; 17:29-35. [PubMed: 15653307]

79. Adib-Conquy M, Scott-Algara D, Cavaillon JM, F. Souza-Fonseca-Guimaraes. TLR-mediated activation of NK cells and their role in bacterial/viral immune responses in mammals. Immunol Cell Biol. 2014; 92:256-262. [PubMed: 24366517]

80. Schuster IS, Wikstrom ME, Brizard G, Coudert JD, Estcourt MJ, Manzur M, O'Reilly LA, Smyth MJ, Trapani JA, Hill GR, Andoniou CE, Degli-Esposti MA. TRAIL+ NK cells control CD4+ T cell responses during chronic viral infection to limit autoimmunity. Immunity. 2014; 41:646-656. [PubMed: 25367576]

81. Izumi Y, Ida H, Huang M, Iwanaga N, Tanaka F, Aratake K, Arima K, Tamai M, Kamachi M, Nakamura H, Origuchi T, Kawakami A, Anderson P, Eguchi K. Characterization of peripheral natural killer cells in primary Sjogren's syndrome: impaired NK cell activity and low NK cell number. The Journal of laboratory and clinical medicine. 2006; 147:242-249. [PubMed: 16697772]

82. Brito-Zeron P, Theander E, Baldini C, Seror R, Retamozo S, Quartuccio L, Bootsma H, Bowman SJ, Dorner T, Gottenberg JE, Mariette X, Bombardieri S, de Vita S, Mandl T, Ng WF, Kruize AA, Tzioufas A, Vitali C, Buyon J, Izmirly P, Fox R, Ramos-Casals M, F. Eular Sjogren Syndrome Task. Early diagnosis of primary Sjogren's syndrome: EULAR-SS task force clinical recommendations. Expert Rev Clin Immunol. 2016; 12:137-156. [PubMed: 26691952]

83. Kawakami A, Nakashima K, Tamai M, Nakamura H, Iwanaga N, Fujikawa K, Aramaki T, Arima K, Iwamoto N, Ichinose K, Kamachi M, Ida H, Origuchi T, Eguchi K. Toll-like receptor in salivary glands from patients with Sjögren's syndrome: functional analysis by human salivary gland cell line. J Rheumatol. 2007; 34:1019-1026. [PubMed: 17407216]

84. Manoussakis MN, Spachidou MP, Maratheftis CI. Salivary epithelial cells from Sjogren's syndrome patients are highly sensitive to anoikis induced by TLR-3 ligation. J Autoimmun. 2010; 35:212-218. [PubMed: 20685081]

85. Kwok SK, Cho ML, Her YM, Oh HJ, Park MK, Lee SY, Woo YJ, Ju JH, Park KS, Kim HY, Park SH. TLR2 ligation induces the production of IL-23/IL-17 via IL-6, STAT3 and NF-kB pathway in patients with primary Sjogren's syndrome. Arthritis Res Ther. 2012; 14:R64. [PubMed: 22417709]

86. Shimizu S, Kurashige Y, Nishimura M, Yamazaki M, Sato J, Saitoh M, Selimovic D, Abiko Y. Involvement of toll-like receptors in autoimmune sialoadenitis of the non-obese diabetic mouse. $\mathrm{J}$ Oral Pathol Med. 2012; 41:517-523. [PubMed: 22394361]

87. Zheng L, Zhang Z, Yu C, Yang C. Expression of Toll-like receptors 7, 8, and 9 in primary Sjögren's syndrome. Oral Surg Oral Med Oral Pathol Oral Radiol Endod. 2010; 109:844-850. [PubMed: 20399690]

88. Liu Y, Yin H, Zhao M, Lu Q. TLR2 and TLR4 in Autoimmune Diseases: a Comprehensive Review. Clin Rev Allergy Immunol. 2013

89. Capes-Davis A, Theodosopoulos G, Atkin I, Drexler HG, Kohara A, MacLeod RA, Masters JR, Nakamura Y, Reid YA, Reddel RR, Freshney RI. Check your cultures! A list of crosscontaminated or misidentified cell lines. Int J Cancer. 2010; 127:1-8. [PubMed: 20143388]

90. Marmary Y, He XJ, Hand AR, Ship JA, Wellner RB. Beta-adrenergic responsiveness in a human submandibular tumor cell line (A253). In Vitro Cell Dev Biol. 1989; 25:951-958. [PubMed: 2572578]

91. Cuello C, Palladinetti P, Tedla N, Di Girolamo N, Lloyd AR, McCluskey PJ, Wakefield D. Chemokine expression and leucocyte infiltration in Sjogren's syndrome. Br J Rheumatol. 1998; 37:779-783. [PubMed: 9714357]

92. Iwamoto N, Kawakami A, Arima K, Nakamura H, Kawashiri SY, Tamai M, Kita J, Okada A, Koga T, Kamachi M, Yamasaki S, Ichinose K, Ida H, Origuchi T, Eguchi K. Regulation of disease susceptibility and mononuclear cell infiltration into the labial salivary glands of Sjogren's syndrome by monocyte chemotactic protein-1. Rheumatology (Oxford). 2010; 49:1472-1478. [PubMed: 20463188]

93. Szodoray P, Alex P, Jonsson MV, Knowlton N, Dozmorov I, Nakken B, Delaleu N, Jonsson R, Centola M. Distinct profiles of Sjögren's syndrome patients with ectopic salivary gland germinal centers revealed by serum cytokines and BAFF. Clin Immunol. 2005; 117:168-176. [PubMed: 16126006] 
94. Roescher N, Tak PP, Illei GG. Cytokines in Sjogren's syndrome. Oral Dis. 2009; 15:519-526. [PubMed: 19519622]

95. Midwood KS, Piccinini AM, Sacre S. Targeting Toll-like receptors in autoimmunity. Curr Drug Targets. 2009; 10:1139-1155. [PubMed: 19715534]

96. Nakamura H, Horai Y, Suzuki T, Okada A, Ichinose K, Yamasaki S, Koji T, Kawakami A. TLR3mediated apoptosis and activation of phosphorylated Akt in the salivary gland epithelial cells of primary Sjögren's syndrome patients. Rheumatol Int. 2013; 33:441-450. [PubMed: 22457005]

97. Ittah M, Miceli-Richard C, Gottenberg JE, Sellam J, Eid P, Lebon P, Pallier C, Lepajolec C, Mariette X. Viruses induce high expression of BAFF by salivary gland epithelial cells through TLR- and type-I IFN-dependent and -independent pathways. Eur J Immunol. 2008; 38:1058-1064. [PubMed: 18350548]

98. Shiboski SC, Shiboski CH, Criswell L, Baer A, Challacombe S, Lanfranchi H, Schiødt M, Umehara H, Vivino F, Zhao Y, Dong Y, Greenspan D, Heidenreich AM, Helin P, Kirkham B, Kitagawa K, Larkin G, Li M, Lietman T, Lindegaard J, McNamara N, Sack K, Shirlaw P, Sugai S, Vollenweider C, Whitcher J, Wu A, Zhang S, Zhang W, Greenspan J, Daniels T, S.s.I.C.C.A.S.R. Groups. American College of Rheumatology classification criteria for Sjögren's syndrome: a datadriven, expert consensus approach in the Sjögren's International Collaborative Clinical Alliance cohort. Arthritis Care Res (Hoboken). 2012; 64:475-487. [PubMed: 22563590]

99. Kyriakidis NC, Kapsogeorgou EK, Gourzi VC, Konsta OD, Baltatzis GE, Tzioufas AG. Toll-like receptor 3 stimulation promotes Ro52/TRIM21 synthesis and nuclear redistribution in salivary gland epithelial cells, partially via type I interferon pathway. Clin Exp Immunol. 2014; 178:548_ 560. [PubMed: 25098814]

100. Thien M, Phan TG, Gardam S, Amesbury M, Basten A, Mackay F, Brink R. Excess BAFF rescues self-reactive $\mathrm{B}$ cells from peripheral deletion and allows them to enter forbidden follicular and marginal zone niches. Immunity. 2004; 20:785-798. [PubMed: 15189742]

101. Lesley R, Xu Y, Kalled SL, Hess DM, Schwab SR, Shu HB, Cyster JG. Reduced competitiveness of autoantigen-engaged B cells due to increased dependence on BAFF. Immunity. 2004; 20:441453. [PubMed: 15084273]

102. Groom J, Kalled SL, Cutler AH, Olson C, Woodcock SA, Schneider P, Tschopp J, Cachero TG, Batten M, Wheway J, Mauri D, Cavill D, Gordon TP, Mackay CR, Mackay F. Association of BAFF/BLyS overexpression and altered B cell differentiation with Sjögren's syndrome. J Clin Invest. 2002; 109:59-68. [PubMed: 11781351]

103. Varin MM, Le Pottier L, Youinou P, Saulep D, Mackay F, Pers JO. B-cell tolerance breakdown in Sjogren's syndrome: focus on BAFF. Autoimmun Rev. 2010; 9:604-608. [PubMed: 20457281]

104. Nocturne G, Mariette X. Sjogren Syndrome-associated lymphomas: an update on pathogenesis and management. Br J Haematol. 2015; 168:317-327. [PubMed: 25316606]

105. Karlsen M, Hansen T, Nordal HH, Brun JG, Jonsson R, Appel S. Expression of Toll-like receptor-7 and-9 in B cell subsets from patients with primary Sjogren's syndrome. PLoS One. 2015; 10:e0120383. [PubMed: 25790192]

106. Karlsen M, Jonsson R, Brun JG, Appel S, Hansen T. TLR-7 and-9 Stimulation of Peripheral Blood B Cells Indicate Altered TLR Signalling in Primary Sjogren's Syndrome Patients by Increased Secretion of Cytokines. Scand J Immunol. 2015; 82:523-531. [PubMed: 26332048]

107. Maria NI, Steenwijk EC, AS IJ, van Helden-Meeuwsen CG, Vogelsang P, Beumer W, Brkic Z, van Daele PL, van Hagen PM, van der Spek PJ, Drexhage HA, Versnel MA. Contrasting expression pattern of RNA-sensing receptors TLR7, RIG-I and MDA5 in interferon-positive and interferon-negative patients with primary Sjogren's syndrome. Ann Rheum Dis. 2016

108. Piccinini AM, Midwood KS. DAMPening inflammation by modulating TLR signalling. Mediators Inflamm. 2010; 2010

109. Chen GY, Nuñez G. Sterile inflammation: sensing and reacting to damage. Nat Rev Immunol. 2010; 10:826-837. [PubMed: 21088683]

110. Kramer JM. Early events in Sjogren's Syndrome pathogenesis: The importance of innate immunity in disease initiation. Cytokine. 2014

111. Enger TB, Samad-Zadeh A, Bouchie MP, Skarstein K, Galtung HK, Mera T, Walker J, Menko AS, Varelas X, Faustman DL, Jensen JL, Kukuruzinska MA. The Hippo signaling pathway is 
required for salivary gland development and its dysregulation is associated with Sjogren's syndrome. Laboratory investigation; a journal of technical methods and pathology. 2013; 93:1203-1218. [PubMed: 24080911]

112. Laine M, Virtanen I, Salo T, Konttinen YT. Segment-specific but pathologic laminin isoform profiles in human labial salivary glands of patients with Sjogren's syndrome. Arthritis Rheum. 2004; 50:3968-3973. [PubMed: 15593200]

113. Yu HB, Finlay BB. The caspase-1 inflammasome: a pilot of innate immune responses. Cell host \& microbe. 2008; 4:198-208. [PubMed: 18779046]

114. Martinon F. Orchestration of pathogen recognition by inflammasome diversity: Variations on a common theme. Eur J Immunol. 2007; 37:3003-3006. [PubMed: 17960661]

115. Lamkanfi M, Dixit VM. Inflammasomes and their roles in health and disease. Annu Rev Cell Dev Biol. 2012; 28:137-161. [PubMed: 22974247]

116. Baldini C, Rossi C, Ferro F, Santini E, Seccia V, Donati V, Solini A. The P2X7 receptorinflammasome complex has a role in modulating the inflammatory response in primary Sjögren's syndrome. J Intern Med. 2013

117. Bulosan M, Pauley KM, Yo K, Chan EK, Katz J, Peck AB, Cha S. Inflammatory caspases are critical for enhanced cell death in the target tissue of Sjögren's syndrome before disease onset. Immunol Cell Biol. 2009; 87:81-90. [PubMed: 18936772]

118. Yamada A, Arakaki R, Kudo Y, Ishimaru N. Targeting IL-1 in Sjögren's syndrome. Expert Opin Ther Targets. 2013

119. Sakai A, Sugawara Y, Kuroishi T, Sasano T, Sugawara S. Identification of IL-18 and Th17 cells in salivary glands of patients with Sjögren's syndrome, and amplification of IL-17-mediated secretion of inflammatory cytokines from salivary gland cells by IL-18. J Immunol. 2008; 181:2898-2906. [PubMed: 18684981]

120. Bombardieri M, Barone F, Pittoni V, Alessandri C, Conigliaro P, Blades MC, Priori R, McInnes IB, Valesini G, Pitzalis C. Increased circulating levels and salivary gland expression of interleukin-18 in patients with Sjogren's syndrome: relationship with autoantibody production and lymphoid organization of the periductal inflammatory infiltrate. Arthritis Res Ther. 2004; 6:R447-456. [PubMed: 15380044]

121. Delaleu N, Immervoll H, Cornelius J, Jonsson R. Biomarker profiles in serum and saliva of experimental Sjogren's syndrome: associations with specific autoimmune manifestations. Arthritis Res Ther. 2008; 10:R22. [PubMed: 18289371]

122. Woods LT, Camden JM, Batek JM, Petris MJ, Erb L, Weisman GA. P2X7 receptor activation induces inflammatory responses in salivary gland epithelium. Am J Physiol Cell Physiol. 2012; 303:C790-801. [PubMed: 22875784]

123. Heward JA, Lindsay MA. Long non-coding RNAs in the regulation of the immune response. Trends Immunol. 2014; 35:408-419. [PubMed: 25113636]

124. Fitzgerald KA, Caffrey DR. Long noncoding RNAs in innate and adaptive immunity. Curr Opin Immunol. 2014; 26:140-146. [PubMed: 24556411]

125. Ponting CP, Oliver PL, Reik W. Evolution and functions of long noncoding RNAs. Cell. 2009; 136:629-641. [PubMed: 19239885]

126. Wang KC, Chang HY. Molecular mechanisms of long noncoding RNAs. Mol Cell. 2011; 43:904914. [PubMed: 21925379]

127. Weng M, Wu D, Yang C, Peng H, Wang G, Wang T, Li X. Noncoding RNAs in the development, diagnosis, and prognosis of colorectal cancer. Transl Res. 2016

128. Long H, Yin H, Wang L, Gershwin ME, Lu Q. The critical role of epigenetics in systemic lupus erythematosus and autoimmunity. J Autoimmun. 2016; 74:118-138. [PubMed: 27396525]

129. Sandhya P, Joshi K, Scaria V. Long noncoding RNAs could be potential key players in the pathophysiology of Sjogren's syndrome. Int J Rheum Dis. 2015; 18:898-905. [PubMed: 26420575]

130. Shi H, Cao N, Pu Y, Xie L, Zheng L, Yu C. Long non-coding RNA expression profile in minor salivary gland of primary Sjogren's syndrome. Arthritis Res Ther. 2016; 18:109. [PubMed: 27188286] 
131. Catalanotto C, Cogoni C, Zardo G. MicroRNA in Control of Gene Expression: An Overview of Nuclear Functions. Int J Mol Sci. 2016; 17

132. Singh RP, Massachi I, Manickavel S, Singh S, Rao NP, Hasan S, Mc Curdy DK, Sharma S, Wong D, Hahn BH, Rehimi H. The role of miRNA in inflammation and autoimmunity. Autoimmun Rev. 2013; 12:1160-1165. [PubMed: 23860189]

133. Hu R, O'Connell RM. MicroRNA control in the development of systemic autoimmunity. Arthritis Res Ther. 2013; 15:202. [PubMed: 23379780]

134. Alevizos I, Alexander S, Turner RJ, Illei GG. MicroRNA expression profiles as biomarkers of minor salivary gland inflammation and dysfunction in Sjogren's syndrome. Arthritis Rheum. 2011; 63:535-544. [PubMed: 21280008]

135. Tandon M, Gallo A, Jang SI, Illei GG, Alevizos I. Deep sequencing of short RNAs reveals novel microRNAs in minor salivary glands of patients with Sjogren's syndrome. Oral Dis. 2012; 18:127-131. [PubMed: 21895886]

136. Chen JQ, Papp G, Szodoray P, Zeher M. The role of microRNAs in the pathogenesis of autoimmune diseases. Autoimmun Rev. 2016; 15:1171-1180. [PubMed: 27639156]

137. Pauley KM, Stewart CM, Gauna AE, Dupre LC, Kuklani R, Chan AL, Pauley BA, Reeves WH, Chan EK, Cha S. Altered miR-146a expression in Sjogren's syndrome and its functional role in innate immunity. Eur J Immunol. 2011; 41:2029-2039. [PubMed: 21469088]

138. Gourzi VC, Kapsogeorgou EK, Kyriakidis NC, Tzioufas AG. Study of microRNAs (miRNAs) that are predicted to target the autoantigens Ro/SSA and La/SSB in primary Sjogren's Syndrome. Clin Exp Immunol. 2015; 182:14-22. [PubMed: 26201309]

139. Zilahi E, Tarr T, Papp G, Griger Z, Sipka S, Zeher M. Increased microRNA-146a/b, TRAF6 gene and decreased IRAK1 gene expressions in the peripheral mononuclear cells of patients with Sjogren's syndrome. Immunology letters. 2012; 141:165-168. [PubMed: 22033216]

140. Chen JQ, Zilahi E, Papp G, Sipka S, Zeher M. Simultaneously increased expression of microRNA-155 and suppressor of cytokine signaling 1 (SOCS1) gene in the peripheral blood mononuclear cells of patients with primary Sjogren's syndrome. Int J Rheum Dis. 2015

141. Shi H, Zheng LY, Zhang P, Yu CQ. miR-146a and miR-155 expression in PBMCs from patients with Sjogren's syndrome. J Oral Pathol Med. 2014; 43:792-797. [PubMed: 24931100]

142. Williams AE, Choi K, Chan AL, Lee YJ, Reeves WH, Bubb MR, Stewart CM, Cha S. Sjogren's syndrome-associated microRNAs in CD14(+) monocytes unveils targeted TGFbeta signaling. Arthritis Res Ther. 2016; 18:95. [PubMed: 27142093]

143. Suarez-Farinas M, Arbeit R, Jiang W, Ortenzio FS, Sullivan T, Krueger JG. Suppression of Molecular Inflammatory Pathways by Toll-Like Receptor 7, 8, and 9 Antagonists in a Model of IL-23-Induced Skin Inflammation. PLoS One. 2013; 8:e84634. [PubMed: 24386404]

144. Travis S, Yap LM, Hawkey C, Warren B, Lazarov M, Fong T, Tesi RJ, R.D.P.I.S. Group. RDP58 is a novel and potentially effective oral therapy for ulcerative colitis. Inflamm Bowel Dis. 2005; 11:713-719. [PubMed: 16043985]

145. Li J, Wang X, Zhang F, Yin H. Toll-like receptors as therapeutic targets for autoimmune connective tissue diseases. Pharmacology \& therapeutics. 2013; 138:441-451. [PubMed: 23531543]

146. ClinicalTrials.gov. National Library of Medicine/ National Institutes of Health. Feb 1.2000 [Web. 04 Apr. 2017]

147. Izmailova ES, Paz N, Alencar H, Chun M, Schopf L, Hepperle M, Lane JH, Harriman G, Xu Y, Ocain T, Weissleder R, Mahmood U, Healy AM, Jaffee B. Use of molecular imaging to quantify response to IKK-2 inhibitor treatment in murine arthritis. Arthritis Rheum. 2007; 56:117-128. [PubMed: 17195214]

148. Mbalaviele G, Sommers CD, Bonar SL, Mathialagan S, Schindler JF, Guzova JA, Shaffer AF, Melton MA, Christine LJ, Tripp CS, Chiang PC, Thompson DC, Hu Y, Kishore N. A novel, highly selective, tight binding IkappaB kinase-2 (IKK-2) inhibitor: a tool to correlate IKK-2 activity to the fate and functions of the components of the nuclear factor-kappaB pathway in arthritis-relevant cells and animal models. J Pharmacol Exp Ther. 2009; 329:14-25. [PubMed: 19168710] 
149. Capolunghi F, Rosado MM, Cascioli S, Girolami E, Bordasco S, Vivarelli M, Ruggiero B, Cortis E, Insalaco A, Fanto N, Gallo G, Nucera E, Loiarro M, Sette C, De Santis R, Carsetti R, Ruggiero V. Pharmacological inhibition of TLR9 activation blocks autoantibody production in human B cells from SLE patients. Rheumatology (Oxford). 2010; 49:2281-2289. [PubMed: 20739362]

150. Broadley SA, Vanags D, Williams B, Johnson B, Feeney D, Griffiths L, Shakib S, Brown G, Coulthard A, Mullins P, Kneebone C. Results of a phase IIa clinical trial of an anti-inflammatory molecule, chaperonin 10, in multiple sclerosis. Mult Scler. 2009; 15:329-336. [PubMed: 19039022]

151. White M, Webster G, O'Sullivan D, Stone S, La Flamme AC. Targeting innate receptors with MIS416 reshapes Th responses and suppresses CNS disease in a mouse model of multiple sclerosis. PLoS One. 2014; 9:e87712. [PubMed: 24498172]

152. Nocturne G, Cornec D, Seror R, Mariette X. Use of Biologics in Sjogren's Syndrome. Rheum Dis Clin North Am. 2016; 42:407-417. [PubMed: 27431344]

153. De Vita S, Quartuccio L, Seror R, Salvin S, Ravaud P, Fabris M, Nocturne G, Gandolfo S, Isola M, Mariette X. Efficacy and safety of belimumab given for 12 months in primary Sjogren's syndrome: the BELISS open-label phase II study. Rheumatology (Oxford). 2015

154. Mariette X, Seror R, Quartuccio L, Baron G, Salvin S, Fabris M, Desmoulins F, Nocturne G, Ravaud P, De Vita S. Efficacy and safety of belimumab in primary Sjogren's syndrome: results of the BELISS open-label phase II study. Ann Rheum Dis. 2015; 74:526-531. [PubMed: 24347569]

155. Mavragani CP. Mechanisms and New Strategies for Primary Sjogren's Syndrome. Annu Rev Med. 2017; 68:331-343. [PubMed: 28099084]

156. Norheim KB, Harboe E, Goransson LG, Omdal R. Interleukin-1 inhibition and fatigue in primary Sjogren's syndrome--a double blind, randomised clinical trial. PLoS One. 2012; 7:e30123. [PubMed: 22253903]

157. Lee JC, Menacherry S, Diehl MC, Giffear MD, White CJ, Juba R, Bagarazzi ML, Muthumani K, Boyer J, Agarwal V, Nicoletti F, Bart S, Kim JJ, Weiner DB, Sardesai NY. Safety, bioavailability, and pharmacokinetics of VGX-1027-A novel oral anti-inflammatory drug in healthy human subjects. Clin Pharmacol Drug Dev. 2016; 5:91-101. [PubMed: 27138022]

158. Fagone P, Muthumani K, Mangano K, Magro G, Meroni PL, Kim JJ, Sardesai NY, Weiner DB, Nicoletti F. VGX-1027 modulates genes involved in lipopolysaccharide-induced Toll-like receptor 4 activation and in a murine model of systemic lupus erythematosus. Immunology. 2014; 142:594-602. [PubMed: 24527796]

159. Vivino FB, Carsons SE, Foulks G, Daniels TE, Parke A, Brennan MT, Forstot SL, Scofield RH, Hammitt KM. New Treatment Guidelines for Sjogren's Disease. Rheum Dis Clin North Am. 2016; 42:531-551. [PubMed: 27431353]

160. Hunter CA, Jones SA. IL-6 as a keystone cytokine in health and disease. Nat Immunol. 2015; 16:448-457. [PubMed: 25898198]

161. Passineau MJ, Fahrenholz T, Machen L, Zourelias L, Nega K, Paul R, MacDougall MJ, Mamaeva O, Steet R, Barnes J, Kingston HM, Benza RL. alpha-Galactosidase A expressed in the salivary glands partially corrects organ biochemical deficits in the fabry mouse through endocrine trafficking. Hum Gene Ther. 2011; 22:293-301. [PubMed: 20858137]

162. Wu C, Wang Z, Zourelias L, Thakker H, Passineau MJ. IL-17 sequestration via salivary gland gene therapy in a mouse model of Sjogren's syndrome suppresses disease-associated expression of the putative autoantigen Klk1b22. Arthritis Res Ther. 2015; 17:198. [PubMed: 26245278] 

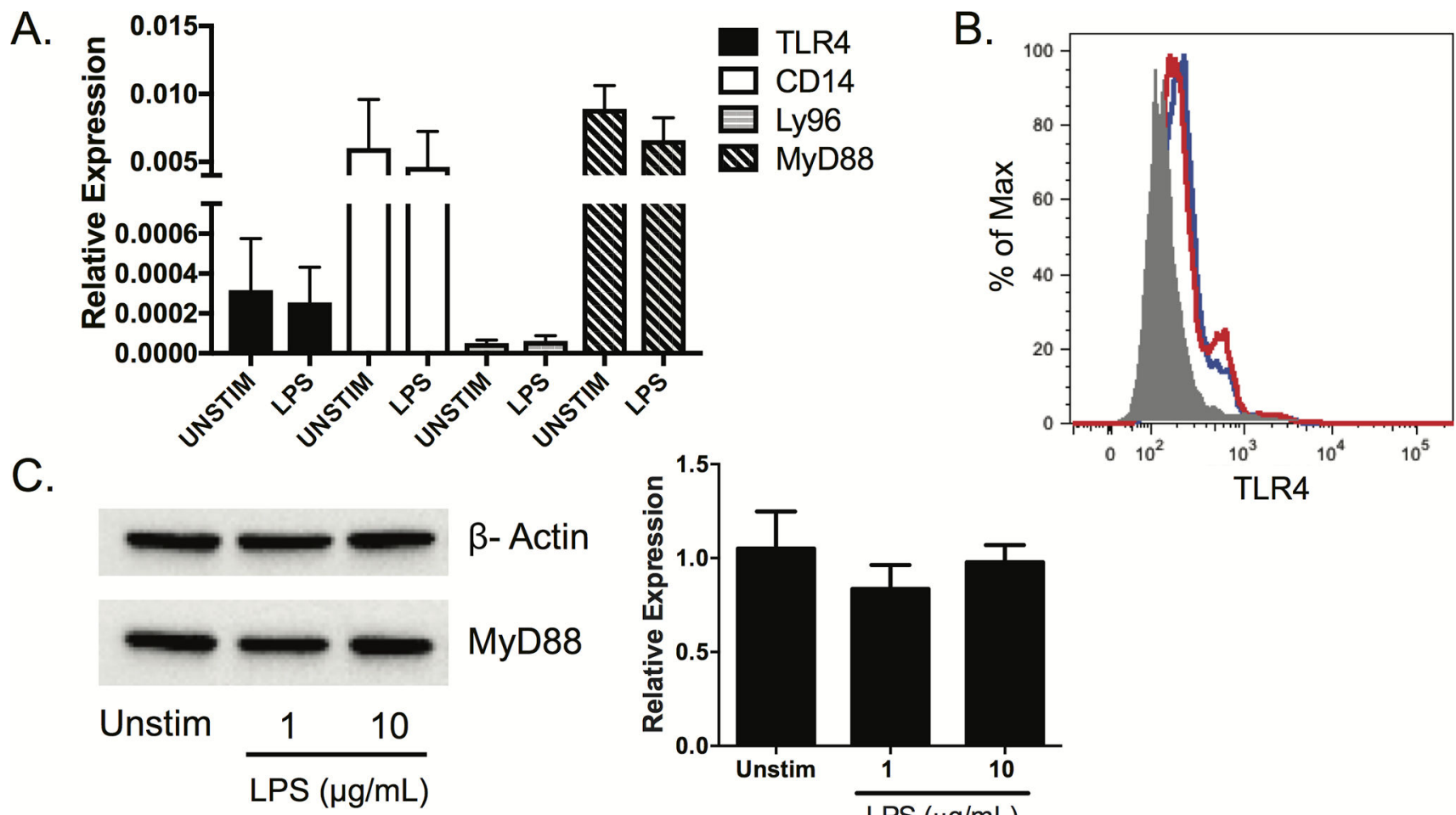

$\beta$-Actin

\section{MyD88}

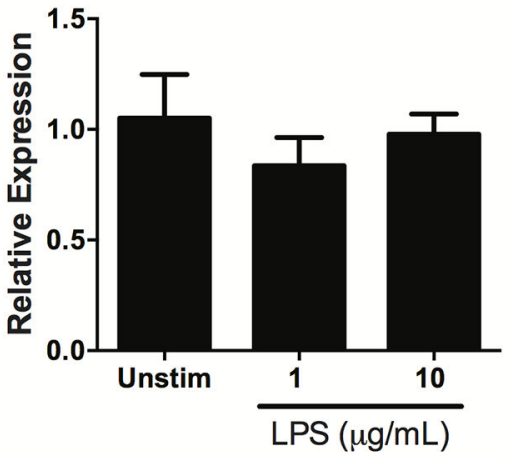

D.
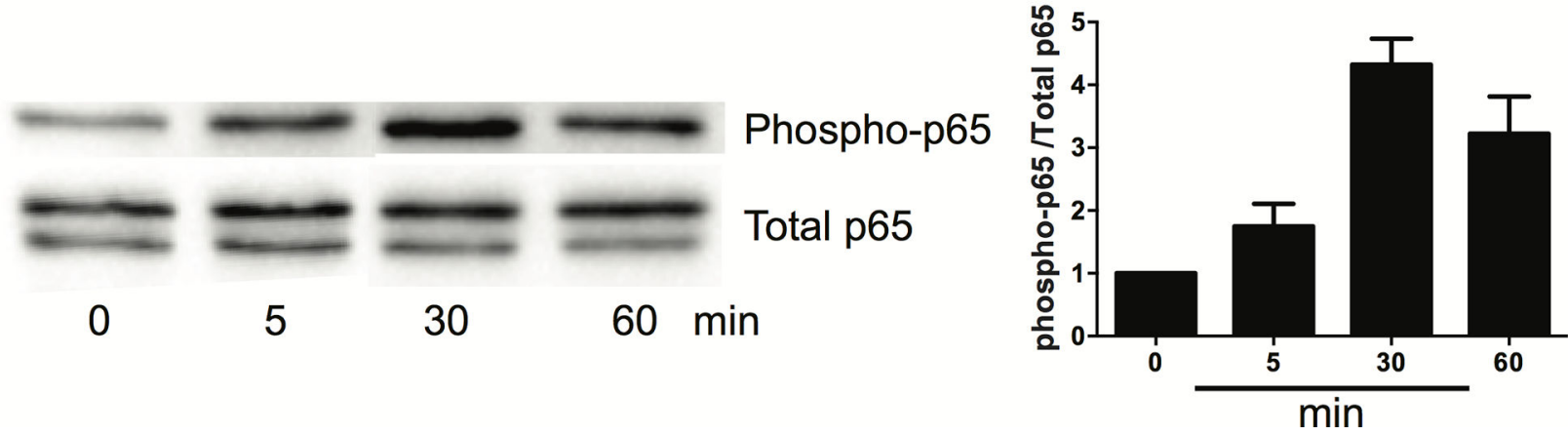

Figure 1. LPS activates TLR4 signaling in A253 cells

A253 cells were purchased from American Type Culture Collection. Cells were cultured in McCoy's 5A (Modified) Media containing 10\% heat-inactivated FBS, 2 mM L-glutamine, $100 \mathrm{U} / \mathrm{mL}$ penicillin, and $100 \mu \mathrm{g} / \mathrm{mL}$ streptomycin in 6 well plates. (A) A253 cells $(3.5 \times$ $10^{5}$ ) were harvested, and relative TLR4, Ly96, CD14, and MyD88 transcript levels were quantified by real time PCR. Each sample was analyzed in duplicate and normalized expression relative to GAPDH is shown. (B) A253 cells were harvested and cultured in the presence or absence of LPS $(10 \mu \mathrm{g} / \mathrm{mL})$ derived from Salmonella typhimurium for $24 \mathrm{~h}$. Tissue was fluorescently stained with isotype control (grey shading) or TLR4 antibody. The red line represents unstimulated cells and the blue line indicates LPS treated cells. (C) A253 cells $\left(3.0 \times 10^{5}\right)$ were incubated in the presence or absence LPS $(10 \mu \mathrm{g} / \mathrm{mL})$ for $24 \mathrm{~h}$. Cells were lysed and western blots performed for MyD88. All samples were normalized to GAPDH. (D) A253 cells $\left(3.0 \times 10^{5}\right)$ were stimulated with LPS $(10 \mu \mathrm{g} / \mathrm{mL})$ for the indicated times. Phosphorylated p65 was normalized to total p65 levels. Results of at least three independent experiments are shown ( $\min =$ minutes $)$. 

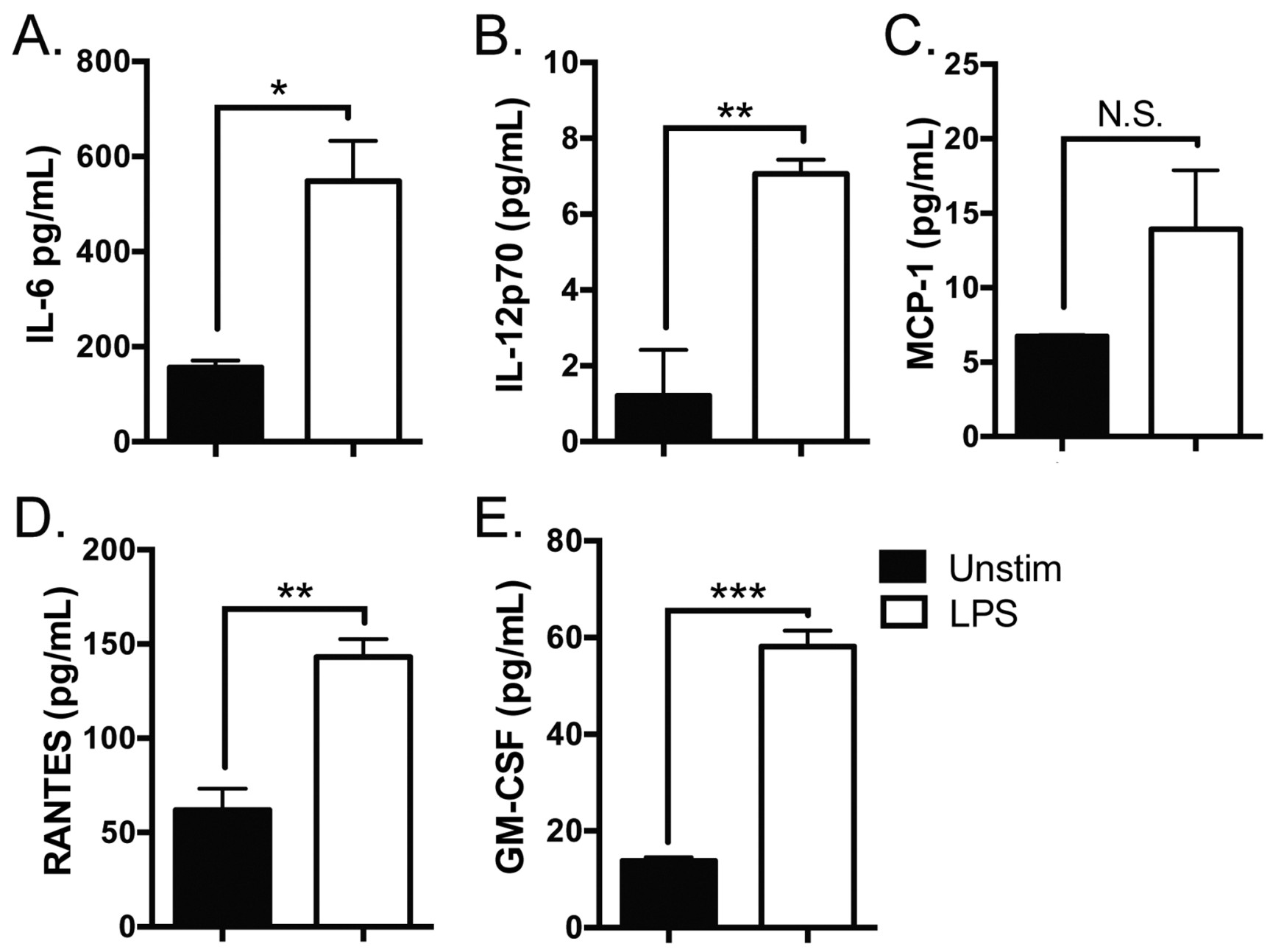

Figure 2. LPS induces inflammatory cytokine secretion in A253 cells A253 cells $\left(3.0 \times 10^{5}\right)$ were cultured in the presence or absence of LPS $(10 \mu \mathrm{g} / \mathrm{mL})$ for $24 \mathrm{~h}$, and the supernatant harvested. (A) IL-6, (B) IL-12, (C) MCP-1, (D) RANTES, and (E) GMCSF were assessed by multiplex array. All samples were analyzed in triplicate and results of three independent experiments are shown $(* \mathrm{p}<0.05$, ** $\mathrm{p}<0.001$, *** $\mathrm{p}<0.0001$, N.S. $=$ non significant). 


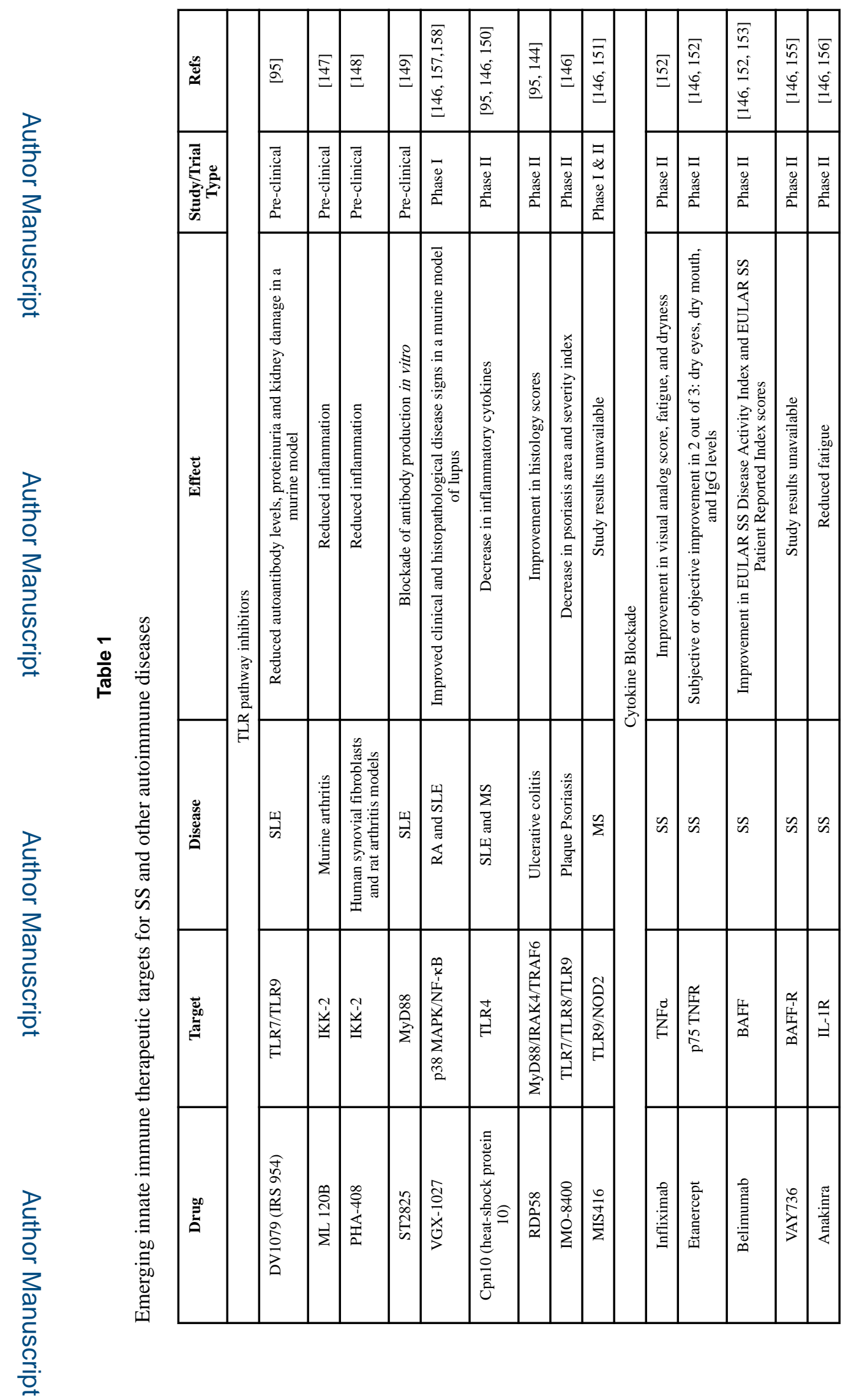

Clin Immunol. Author manuscript; available in PMC 2018 September 01. 